\title{
Altered of apoptotic markers of both extrinsic and intrinsic pathways induced by hepatitis $C$ virus infection in peripheral blood mononuclear cells
}

Guilherme Albertoni ${ }^{1,4^{*}}$, Carine Prisco Arnoni ${ }^{1}$, Flávia Roche Moreira Latini ${ }^{1}$, Sheila Siqueira Andrade ${ }^{1,2}$, Patrícia Regina Barboza Araújo 1, Flaviane Kesia Rodrigues³, Patrícia Bortman Rozenchan 1,2, Maria Cássia Mendes-Correa ${ }^{3}$, Olavo Henrique Munhoz Leite ${ }^{3}$, Nestor Schor ${ }^{4}$, Manoel João Castelo Batista Girão ${ }^{2}$ and José Augusto Barreto ${ }^{1}$

\begin{abstract}
Background: Chronic hepatitis C (CHC) has emerged as a leading cause of cirrhosis in the U.S. and across the world. To understand the role of apoptotic pathways in hepatitis $\mathrm{C}$ virus (HCV) infection, we studied the mRNA and protein expression patterns of apoptosis-related genes in peripheral blood mononuclear cells (PBMC) obtained from patients with HCV infection.

Methods: The present study included 50 subjects which plasma samples were positive for HCV, but negative for human immunodeficiency virus (HIV) or hepatitis B virus (HBV). These cases were divided into four groups according to METAVIR, a score-based analysis which helps to interpret a liver biopsy according to the degree of inflammation and fibrosis. mRNA expression of the studied genes were analyzed by reverse transcription of quantitative polymerase chain reaction (RT-qPCR) and protein levels, analyzed by ELISA, was also conducted. HCV genotyping was also determined.

Results: HCV infection increased mRNA expression and protein synthesis of caspase 8 in group 1 by 3 fold and 4 fold, respectively $(p<0.05)$. In group 4 HCV infection increased mRNA expression and protein synthesis of caspase 9 by 2 fold and 1,5 fold, respectively $(p<0.05)$. Also, caspase 3 mRNA expression and protein synthesis had level augumented by HCV infection in group 1 by 4 fold and 5 fold, respectively, and in group 4 by 6 fold and 7 fold, respectively $(p<0.05)$.
\end{abstract}

Conclusions: HCV induces alteration at both genomic and protein levels of apoptosis markers involved with extrinsic and intrinsic pathways.

Keywords: HCV infection, Apoptosis, Caspase 3, Caspase 8, Caspase 9

\section{Background}

Hepatitis $\mathrm{C}$ virus (HCV) is a major worldwide causative pathogen of chronic hepatitis (CHC), cirrhosis, and hepatocellular carcinoma [1]. Although the exact mechanisms governing the elements of HCV pathogenesis, such as viral persistence, hepatocyte injury, and

\footnotetext{
* Correspondence: albertonig@nefro.epm.br

'Colsan - Associação Beneficente de Coleta de Sangue, São Paulo, SP, Brazil ${ }^{4}$ Department of Nephrology, Federal University of São Paulo (UNIFESP), São Paulo, SP, Brazil

Full list of author information is available at the end of the article
}

hepatocarcinogenesis, are not fully understood, an accumulating body of evidence suggests that apoptosis of hepatocytes and peripheral blood mononuclear cells (PBMCs) are significantly involved [2,3]. Apoptosis plays a pivotal role in the maintenance of cellular homeostasis through removal of aged, damaged, and hyperproliferative cells [4]. Resistance to apoptosis induced by various stimuli is one of the most important factors in tumor progression, as well as in resistance to cytotoxic therapies [5]. In mammalian cells, apoptosis can be induced via two major pathways. One is the death receptor pathway

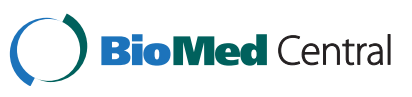


(extrinsic pathway), which is triggered by binding of FAS ligand (FASLG) to FAS (CD95). This leads to activation of caspase 8 (CASP8), which subsequently activates effector caspases 3, 6, and 7 (CASP3, CASP6, and CASP7) [6-9]. The second apoptosis pathway (intrinsic pathway) is induced by mitochondria in response to DNA damage, oxidative stress, and viral proteins [2]. Mitochondriondependent apoptosis is mediated by pro-apoptotic genes ( $B A X, B A D, B A K$, and others), whereas proteins like BCL-2 and BCL-XL are anti-apoptotic. These proteins converge at the mitochondrial permeability transition pore, which regulates the release of apoptotic regulatory proteins such as procaspase- 9 and cytochrome c (CYCS) [10].

Some studies have indicated that apoptosis of hepatocytes plays a significant role in the pathogenesis of $\mathrm{HCV}$ infection [11-14], which is clinically recognized as liver inflammation and fibrosis. To date, other alternative sites of HCV replication, such as the PBMCs have been recognized $[15,16]$. Therefore, $\mathrm{CHC}$ should be considered as a systemic disease rather than a local one [8]. Moreover, the HCV ability to directly infect those cells might affect their function and down-modulate apoptotic events, thereby allowing virus chronic replication in target cells. However, the susceptibility of PBMCs to apoptotic process in course of chronic HCV infection has not yet been fully understood [13]. Therefore, the aim of this work was to evaluate in PBMCs obtained from chronic $\mathrm{HCV}$ patients the genomic and protein expression of 3, 8, 9 capases as well as Fas and, CYCS which are involved with intrinsic and extrinsic apoptotic pathways.

\section{Results}

\section{Clinical aspects}

The present study includes a total of 100 subjects, being 50 of them infected by HCV virus. These patients were divided into four groups, according to the degree of fibrosis and inflammation, scored by METAVIR. In the control group, 25 men and 25 women were selected. Subjects with diabetes mellitus, hypertension, connective tissue disease, other systemic diseases, acute or chronic inflammatory disorders, infections, or hepatocellular carcinoma or other malignancy, as well as alcoholics and smokers, were excluded. All patients signed informed consents before inclusion and the ethical committee has approved the protocol, which was in accordance with the ethical guidelines of 1975 Declaration of Helsinki. Table 1 shows the patients distribution according clinical features.

\section{Alterations in apoptotic markers in PBMCs}

We first analyzed genes involved with the extrinsic apoptosis pathway by measuring the expression levels of FAS and CASP8 in PBMCs. In group 1, we observed a 7.5 fold increase in relative $F A S$ expression compared to control group, $\mathrm{p}<0.05$. However, FAS expression was decreased by 5 fold in group 4 compared to control group, $\mathrm{p}<0.05$ (Figure 1 ). We did not observe any significant difference in $F A S$ expression when comparing groups 2 and 3 with the control group. We then analyzed CASP8 relative expression and observed a statistically significant increase of 3 fold change for group 1 when compared to control group, $\mathrm{p}<0.05$ (Figure 2a).

To validate these results, we decided to analyze CASP8 at protein level and observed, by ELISA, that only group 1 has CASP8 increased by 4 fold when compared to control group, $\mathrm{p}<0.05$ (Figure $2 \mathrm{~b}$ ).

We next investigated whether intrinsic apoptosis could possibly be involved in $\mathrm{HCV}$ infection through analysis of relative expression of CASP9 and CYCS in PBMCs. We observed that both were significantly increased in group 4 when compared to the control group. Specifically, there was an increase of 2 fold in CASP9 expression and 5 fold change in CYCS expression (Figures $3 \mathrm{a}$ and 4). No differences were observed for groups 1, 2, or 3 when compared to control group. To confirm our results, we also evaluated CASP9 protein levels in group 4 and the control group, and found that the difference in mRNA expression was reflected in the protein levels. Specifically, we observed a 1.5 fold increase in group 4 over the control group, $\mathrm{p}<0.05$ (Figure $3 \mathrm{~b}$ ).

Since CASP3 increased levels has already been associated with activation of both the extrinsic and intrinsic

Table 1 Patients characteristics/variables

\begin{tabular}{lccccc}
\hline Parameter/Variables Mean $\mathbf{\pm}$ S.D. & Group $\mathbf{1}(\boldsymbol{n}=\mathbf{1 3})$ & Group $\mathbf{2}(\boldsymbol{n}=\mathbf{1 3})$ & Group $\mathbf{3}(\boldsymbol{n}=\mathbf{1 3})$ & Group 4 $(\boldsymbol{n}=\mathbf{1 1})$ & Control Group $(\boldsymbol{n}=\mathbf{5 0})$ \\
\hline ALT $(\mathbf{m g} / \mathbf{d l})$ & $32.1 \pm 4.7^{*}$ & $21.2 \pm 2.8$ & $19.9 \pm 5.0$ & $101.8 \pm 5.0^{* *}$ & $17.2 \pm 6.1$ \\
AFP $(\mathbf{n g} / \mathbf{m l})$ & $39.47 \pm 0.2^{* *}$ & $13.65 \pm 0.1$ & $16.82 \pm 0.8^{* *}$ & $56.76 \pm 0.5^{* *}$ & $10.03 \pm 0.1$ \\
Viral load $(\mathbf{I U} / \mathbf{m l})$ & $66.571 \pm 3196$ & $495.358 \pm 2821$ & $3.568 .588 \pm 2207$ & $11.174 .667 \pm 6385$ & - \\
Age (Mean) & $47.8 \pm 2.05$ & $44.1 \pm 1.58$ & $46.9 \pm 1.59$ & $55.0 \pm 2.98$ & $45.0 \pm 2.4$ \\
Male:female ratio & $1: 1$ & $1.8: 1$ & $2.3: 1$ & $6.0: 1$ & $1: 1$ \\
Genotype & $1 \mathrm{~b} / 1 \mathrm{a}(73,13 \%)$ & & $3(26,87 \%)$ & & \\
\hline
\end{tabular}

ALT, alanine aminotransferase (ALT normal range = Less than $20 \mathrm{mg} / \mathrm{dl}$ (Park et al., 2011); AFP, a-fetoprotein (AFP normal range = Less than $20 \mathrm{ng} / \mathrm{ml}$ (Sato et al., 1993); $\left(^{*}\right) p<0.05$ vs. CTL; $(* *) p<0.0001$ vs. CTL. 


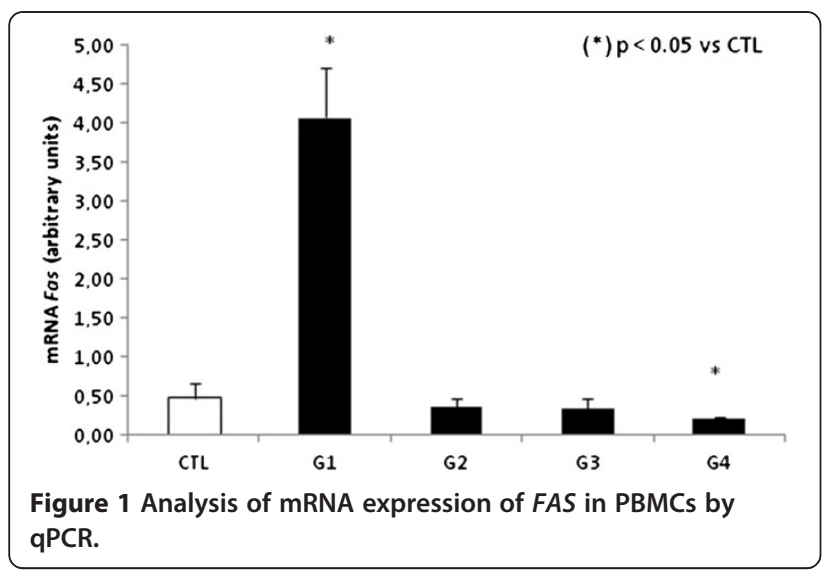

apoptosis pathways [2], we also decided to analyze this caspase at genomic and protein level. mRNA expression showed a 4 fold increase in group 1, p $<0.05$ and 6 fold increase for group 4 in CASP3 expression levels compared to control group (Figure 5a).

To measure CASP3 protein levels we standardized an "in-house" ELISA because a commercial assay kit for this protein was not available. As expected, we found an augment in groups 1 ( 5 fold increase, $\mathrm{p}<0.05$ ) and 4 (7 fold increase, $\mathrm{p}<0.05)$ when compared to control group. (Figure 5b).
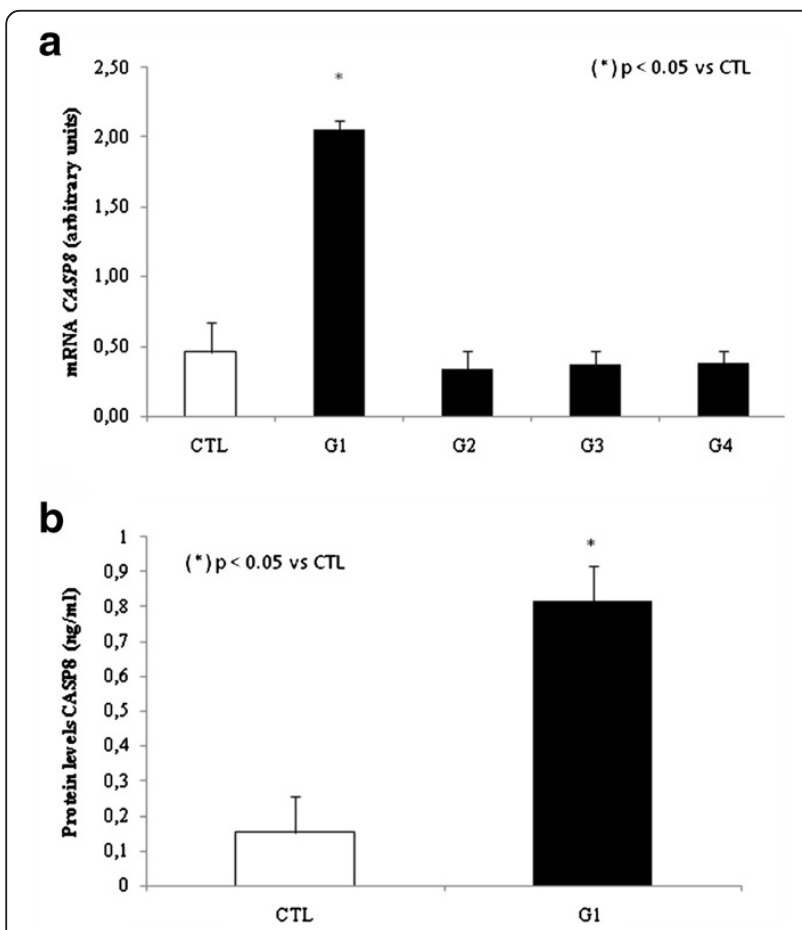

Figure 2 a. Analysis of mRNA expression CASP8 in PBMCs by qPCR. b. Analysis of protein levels of CASP8 in plasma.

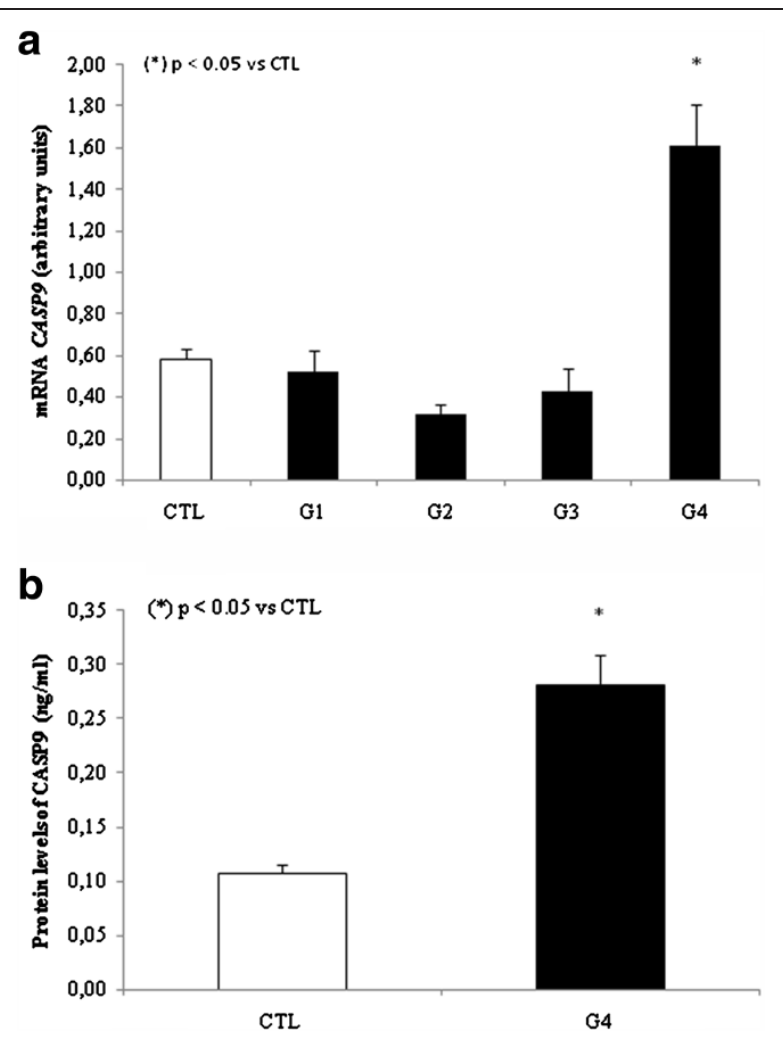

Figure 3 a. Analysis of mRNA expression CASP9 in PBMCs by qPCR. $\mathbf{b}$. Analysis of protein levels of CASP9 in plasma.

\section{Discussion}

$\mathrm{HCV}$ often establishes itself as a persistent infection that causes $\mathrm{CHC}$, liver cirrhosis, and hepatocellular carcinoma, which are significant health problems throughout the world [1]. Despite increasing knowledge of the molecular virology of $\mathrm{HCV}$ and associated apoptosis markers, the mechanisms of hepatocellular injury in $\mathrm{HCV}$ infection are not fully understood. A delicate balance normally exists in cells between antiapoptotic and proapoptotic regulators to ensure the proper survival and turnover of different body cells [17].

In our study, we analyzed the influence of liver inflammation and fibrosis in $\mathrm{CHC}$ patients on the gene

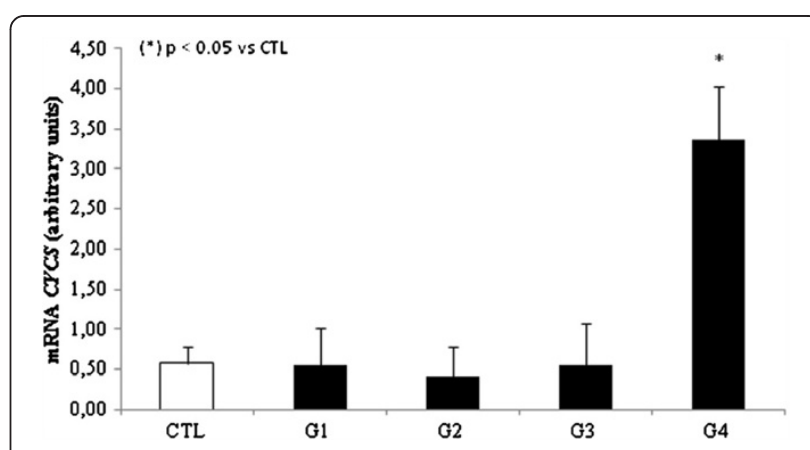

Figure 4 Analysis of mRNA expression CYCS in PBMCs by qPCR. 


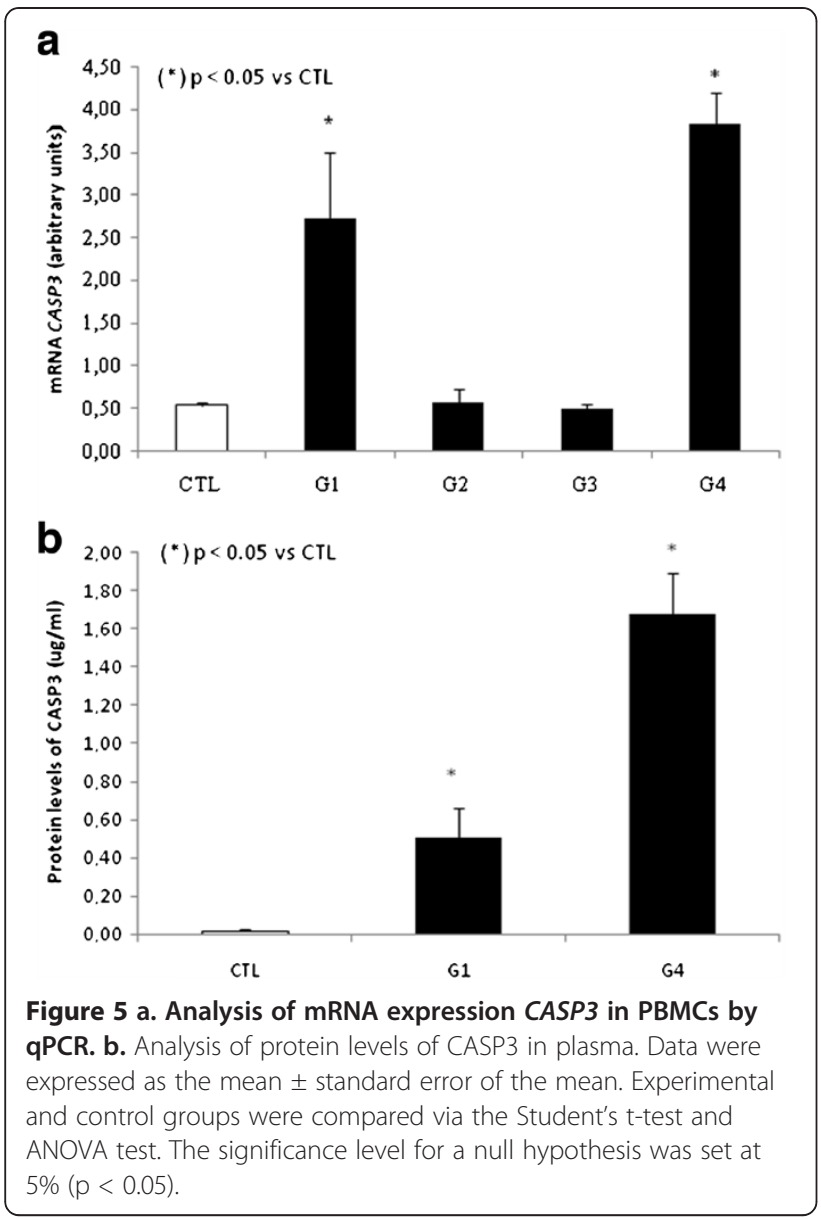

expression of $F A S$ receptor, $C A S P 3, C A S P 8, C A S P 9$, and $C Y C S$ in PBMCs. Further, we examined protein levels of CASP3, CASP8, and CASP9 in plasma samples. These factors are actively involved in apoptotic cell death, and could indirectly indicate the susceptibility of cells to apoptotic death. The apoptotic process seems to be the host's defense mechanism against viral infections, resulting in interruption of viral replication and elimination of infected cells. FASL presented on activated $\mathrm{CD}^{+}$cytotoxic $\mathrm{T}$ cells interacts with overexpressed FAS receptors to trigger apoptosis in infected hepatocytes and PBMCs. The mechanisms for persistence of $\mathrm{HCV}$ infection are complex because of divergent virus strategies for immune system evasion. Under physiological conditions, FAS-FASLG interactions protect immunological homeostasis by regulating apoptosis of various immune cells [18].

We observed significantly increased expression of $F A S$ receptor in PBMCs in patients from group 1. FAS receptor expression may represent a self-limiting mechanism of the immune response [19]. HCV genotype-dependent differences in FAS expression cells have already been described [20] and support the hypothesis that HCV genotype 1 might induce apoptosis [21,22], this could possibly be the reason for our results since genotype 1 was the most prevalent (73\%) in our samples (Table 1). In the other hand, for group 4, we observed a decrease in FAS expression in PBMCs, and this was significantly associated with cirrhosis and intense necroinflammation. This result was supported by the hypothesis suggested elsewhere [21] that reduced expression of FAS receptor is associated with aggressive forms of hepatocellular carcinoma, especially in poorly differentiated tumors that present portal vein or extracapsular invasion, this mechanism could possibly going on in our model. In group 1 , we observed a significant increase in CASP8 expression. Activation of CASP8 via FAS receptor is an important mechanistic initiator of apoptosis in physiological and pathological conditions, and is extremely important in the pathophysiology of CHC [18].

The activation of caspases can be triggered via death receptors or by mitochondrial dysfunction, with the latter resulting in the release of CYCS [23]. The translocation of pro-apoptotic proteins to the mitochondria results in the release of CYCS from outer and inner mitochondrial membrane into the cytosol. In the cytosol, CYCS forms a complex with apoptosis-activating factors, leading to the activation of CASP9, which activates effector caspases.

Group 4 showed a significant increase of CASP9 and CYCS , this found was already supported by at least another group that reported same results associated with significant increases in ALT and AFP levels [24]. The indirect markers of fibrosis reflect alterations in hepatic function. A large number of indirect serum markers of fibrosis have been tested over the past few years. They mainly include AST and ALT levels, tested either alone or in combination [25]. In our study, we observed significantly increased ALT levels in group 4. The increased ALT levels had been associated to mitochondrial injury, which may be related to HCV infection, and is usually predominant in liver cirrhosis [26-29]. AFP is also important in the diagnosis of hepatocellular carcinoma [30]. In the present study, AFP was the most efficient marker for patients in group 4 with liver cirrhosis, confirming the findings of Mohamed et al. [31]. With regard to the correlation of viral load with biochemical markers, we found a positive and strong correlation of ALT levels in group 4, and a positive and moderate correlation with AFP levels in the same group [32]. In groups 2 and 3, we found similar levels of ALT and AFP when compared to control group. Corroborating to these results, CASP3, CASP8, and CASP9 mRNA expression levels were also the same as in the control group.

CASP8 and CASP9 are the key initiator caspases activated through the death-receptor and mitochondrial pathways, respectively $[33,34]$, while CASP3 is the critical effector caspase of both pathways. In both groups 1 
and 4, we observed a significant increase in CASP3 expression, suggesting a possibly activation of apoptosis.

\section{Conclusions}

In summary, the results of this study corroborate to the body of evidence that HCV could induce the augment of some apoptotic markers suggesting that perhaps apoptosis might be activated through both extrinsic and intrinsic pathways. CASP8 is normally activated through the extrinsic pathway, which is triggered by tumor necrosis factor receptor and FAS receptor [8]. In contrast, CASP9 is activated through the intrinsic pathway, which can be initiated by DNA damage and various extracellular stresses [33]. Both pathways induce CASP3, causing its cleavage and ultimately apoptosis. This is in agreement with our results showing increased CASP3 levels in both groups 1 and 4, where the levels of CASP8 and CASP9, respectively, were also increased. Nevertheless, further investigations are necessary to evaluated if this caspases are being activated in PBMCs of HCV infected patients.

\section{Methods}

Patients and histological evaluation of biopsy samples

The present study was prospective and included 50 cases with plasma samples that were positive for RNA-HCV and negative for HIV/HBV by real-time PCR (RT-PCR). Blood samples were collected from patients diagnosed at the Unidade de Referência para Doenças Infecciosas Preveníveis (Urdip) from Faculdade de Medicina do ABC, São Paulo, between June and September 2010. Data included age and gender. We also analyzed liver biopsies (Metavir histologic score) [35], and liver function was estimated by measuring alanine transaminase (ALT) and $\alpha$-fetoprotein (AFP) levels.

These cases were divided into 4 groups according to the METAVIR scoring system after histological evaluation of 50 paraffin-embedded liver specimens [35]. Liver histological staging was based on the degree of fibrosis and inflammatory activity, and the samples were classified into 4 groups: group $1(n=13)$, fibrosis normal and necroinflamation absent; group $2(n=14)$, portal tract fibrosis and mild necroinflamation; group 3 $(n=12)$, few septa and moderate necroinflammation; and group $4(n=11)$, cirrhosis and intense necroinflammation. We also collected 50 samples of healthy individuals for control group $(n=50)$.

\section{Estimation of AFP and ALT levels}

AFP levels were assessed using commercial available ELISA assay kit (IBL America, Minneapolis, MN), according to the manufacturer's recommendations. The cut-off value of AFP was set at $20 \mathrm{ng} / \mathrm{mL}$, the most commonly used value [36,37].
Plasma ALT values were determined with a Hitachi 7050 automatic analyzer (Hitachi Corp., Tokyo, Japan) using commercial available assay kits (Wako Chemicals). The cut-off value for this assay was also set at $20 \mathrm{mg} /$ $\mathrm{mL}$, as well established in the literature [38].

\section{Detection of HIV, HCV, and HBV RNA/DNA by magnetic bead isolation and polymerase chain reaction (PCR)}

Total RNA/DNA was extracted and purified using magnetic bead technology with the appropriate kit (Chemagic Viral DNA/RNA kit). Three-hundred microliters of plasma was used for each assay, and $100 \mu \mathrm{L}$ of lysis buffer was added to each sample. The samples were then vortexed and incubated at room temperature for $10 \mathrm{~min}$. Subsequently, $150 \mu \mathrm{L}$ of the magnetic beads was added, and the mixture was incubated at room temperature for 20 min, with agitation every $10 \mathrm{~min}$. Two-hundred microliters of wash solution was then added, and again, the tubes were vortexed to wash the magnetic beads. Finally, the beads were resuspended with $50 \mu \mathrm{L}$ of elution buffer. The isolated RNA/DNA $(15 \mu \mathrm{L})$ was used in PCR reactions for the detection of viral RNA (HIV or HCV) or DNA (HBV). PCR was performed with primers selective for HIV, HCV, and HBV (Table 2) [39].

When we analyzed presence of HIV and HCV, RNA was reverse-transcribed into cDNA by the addition of Superscript III Platinum ${ }^{\circledR}$ One-Step reaction mix containing all necessary reagents for amplification. Amplification was performed using a 7500 Real-Time Sequence Detection System (SDS; ABI Prism 7500; Applied

Table 2 Primer and probe sequences for the studied genes

\begin{tabular}{|c|c|}
\hline Primers and probe & Sequences genes \\
\hline Fas $R$ & 5'- GGTGCAAGGGTCACAGTGTT-3' \\
\hline Fas $F$ & 5'- TGAAGGACATGGCTTAGAAGTG-3' \\
\hline Caspase $3 R$ & 5'- TGTCGGCATACTGTTTCAGCA-3' \\
\hline Caspase $3 F$ & $5^{\prime}-$ GCAGCAAACCTCAGGGAAAC-3' \\
\hline Caspase $8 R$ & 5'- TCGCCTCGAGGACATCGCTCTC-3' \\
\hline Caspase $8 F$ & 5'- CTGCTGGGGATGGCCACTGTG-3' \\
\hline Caspase $9 R$ & 5'- TCTAAGCAGGAGATGAACAAAGG-3' \\
\hline Caspase $9 F$ & 5'- GGACATCCAGCGGGCAGG-3' \\
\hline Cytochrome $C R$ & $5^{\prime}-$ TCTCCCCAGATGATGCCTTT-3' \\
\hline Cytochome CF & 5'- CAAGACTGGGCCAAATCTCC-3 \\
\hline HCV R & 5'- CGCGACCCAACACTACTC-3' \\
\hline HCV F & 5'- CGGGAGAGCCATAGTGGT-3' \\
\hline HCV PROBE & FAM - TGCGGAACCGGTGAGTACACC - MGB \\
\hline$H B V R$ & $5^{\prime}-$ GGACAAACGGGCAACATACC-3' \\
\hline HBV F: & $5^{\prime}$ - ATGTGTCTGCGGCGTTTTATC-3' \\
\hline HBV PROBE: & FAM - TCCTCTTCATCCTGCTGCTATGCCTCATCT - MGB \\
\hline
\end{tabular}


Biosystems, CA). RT-PCR product accumulation was monitored using a TaqMan probe $[39,40]$.

\section{Standardartization for detection of HCV viral load}

Total RNA was extracted and purified using magnetic bead technology with the appropriate kit (Chemagic Viral DNA/RNA kit). The standard used for HCV realtime RT-PCR was the commercial HCV RNA-positive human plasma (Accurun 306; BBI Diagnostics, SeraCare, MA) kit which was tested in triplicate. Ten-fold dilutions of this standard were made down to $310 \mathrm{IU} / \mathrm{mL}$ by using normal human plasma, and used in all runs to generate standard curves. Dilutions of this standard were tested with a total of 24 replicates for each point dilution to determine the positive cut-off point or lower limit of detection. RT-PCR product accumulation was monitored using a TaqMan probe $[39,40]$.

\section{RNA extraction, CDNA synthesis, and quantitative RT-PCR (qRTPCR) of FAS, CASP3, CASP8, CASP9, and CYCS in PBMCs}

Total RNA was purified from PBMCs by phenol and guanidine isothiocyanate-cesium chloride method (Trizol; Life Technologies). RNA was reverse-transcribed into cDNA by addition of a mixture containing $0.5 \mathrm{mg} /$ $\mathrm{mL}$ oligo $\mathrm{d}(\mathrm{T}), 10 \mathrm{mM}$ DTT, $0.5 \mathrm{mM}$ dNTPs (Pharmacia Biotech, Sweden), and $200 \mathrm{U}$ of reverse transcriptase (SuperScript RT, Gibco-BRL). Real-time amplification was performed using a 7500 Real-Time Sequence Detection System (SDS; ABI Prism 7500; Applied Biosystems, $\mathrm{CA})$. Reactions were cycled 40 times under the conditions previously determined by conventional PCR. PCR was performed with primers selective for $F A S, C A S P 3$, CASP8, CASP9, and CYCS (Table 2). Results from these experiments, per group, are reported as the relative expression normalized to the $\beta$-globin housekeeping gene (Applied Biosystems, CA), used as endogenous control [41,42]. RT-PCR product accumulation was monitored using a Syber Green probe.

The cycle threshold $(\mathrm{Ct})$ values were subtracted from the housekeeping gene $\mathrm{Ct}$ value for each gene to yield $\Delta \mathrm{Ct}$ values. These values were used to carry out statistical comparisons. For graphical representations, the fold-variation was determined using the $2^{-(\Delta \Delta \mathrm{Ct})}$ method, according to published protocols and the manufacturer's recommendations [43].

\section{Analysis of CASP8 and CASP9 protein levels using enzyme-linked immune sorbent assay (ELISA)}

The plasma levels of CASP8 and CASP9 were assessed using commercially available capture ELISA (IBL America, Minneapolis, MN). Both assays were performed according to the manufacturer's protocols. The optical density of each sample was determined using an Ultra
Microplate Reader (EL808; Bio-Tek Instruments, VT) and expressed as $\mathrm{ng} / \mathrm{mL}[44,45]$.

\section{Standardization and analysis of CASP3 protein levels}

A microplate was pre-coated with a polyclonal avidinconjugated antibody specific for CASP3. Standard curve was performed by adding $100 \mathrm{uL}$ of CASP3 peptide (0-20 ng/mL) (Abcam Inc, Cambridge, MA) and samples were added to each well. Samples were then incubated for $2 \mathrm{~h}$ at room temperature. After this incubation period, samples were aspirated from the well and washed 4 times by filling each well with PBS-Tween 20. Next, $100 \mu \mathrm{L}$ of antibody with streptavidin conjugated to horseradish peroxidase (Abcam Inc, Cambridge, MA) was added, and the mixture was incubated for $1 \mathrm{~h}$ at room temperature before repeating the aspiration/wash procedure. One hundred microliters of tetramethylbenzidine and hydrogen peroxide were then added to each well, and the mixture was incubated for $30 \mathrm{~min}$ at room temperature before the addition of $100 \mu \mathrm{L}$ of $1 \mathrm{~N}$ hydrochloric acid to each well. The optical density of each well was determined using a microplate reader set to $450 \mathrm{~nm}$. To determine the CASP3 concentration $(\mathrm{ng} / \mathrm{mL})$ of each sample, we first plotted the absorbance value on the y-axis and extended a horizontal line to the standard curve. At the point of intersection, a vertical line was extended to the $\mathrm{x}$-axis, and the corresponding value was the active caspase- 3 concentration.

\section{HCV genotyping}

After HCV RNA extraction using magnetic beads, samples were genotyped through sequencing of $5^{\prime}$ UTR in a 3500XL genetic analyzer (Applied Biosystems, CA, USA). Primers sequences and protocol were performed as described previously [46].

\section{Statistical analysis}

Data are expressed as the mean \pm standard error of the mean (SEM) values. Experimental and control groups were compared using the Student's t-test for protein levels of CASP8 and CASP9, and ANOVA for the gene expression analysis. The significance level for a null hypothesis was set at 5\% ( $\mathrm{p}<0.05)$. Pearson's correlation analysis in Microsoft Excel (Microsoft Corp., WA) was used to determine the relationship between HCV viral load and ALT/AFP levels [47].

The Research Ethics Committee of University Federal of São Paulo/Sao Paulo Hospital examined and approved this research project (no. 0080/10).

\section{Abbreviations}

CHC: Chronic hepatitis C; HCV: Hepatitis C virus; PBMC: Peripheral blood mononuclear cells; HIV: Human immunodeficiency virus; HBV: Hepatitis B virus; RT-PCR: Reverse transcription of polymerase chain reaction; CASP3: Caspase 3; CASP6: Caspase 6; CASP7: Caspase 7; CASP8: Caspase 8; 
CASP9: Caspase 9; CYCS: Cytochrome c; ALT: Alanine transaminase; AFP: a-fetoprotein.

\section{Competing interests}

The authors declare that they have no conflicts of interest relevant to the manuscript submitted to VIROLOGY JOURNAL.

\section{Authors' contributions}

GA, CPA, SSA, PRBA, FKR designed and carried out the study. and GA, FRML, MCMC, OHML, PBR, NS, MJCBG and JAB wrote the manuscript. All authors read and approved the final manuscript.

\section{Acknowledgments}

This work was aided by grants from Associação Beneficente de Coleta de Sangue (COLSAN), Conselho Nacional de Desenvolvimento Científico Tecnológico (CNPq), Financiadora de Estudos e Projetos (FINEP), Fundação de Amparo à Pesquisa do Estado de São Paulo (FAPESP), and Coordenação de Aperfeiçoamento de Pessoal de Nível Superior (CAPES).

\section{Author details}

${ }^{1}$ Colsan - Associação Beneficente de Coleta de Sangue, São Paulo, SP, Brazil. ${ }^{2}$ Department of Gynecology, Federal University of São Paulo (UNIFESP), São Paulo, SP, Brazil. ${ }^{3}$ URDIP - Unidade de Referência para Doenças Infecciosas Preveníveis, São Paulo, SP, Brazil. ${ }^{4}$ Department of Nephrology, Federal University of São Paulo (UNIFESP), São Paulo, SP, Brazil.

Received: 26 April 2012 Accepted: 7 December 2012 Published: 20 December 2012

\section{References}

1. Shepard CW, Finelli L, Alter MJ: Global epidemiology of hepatitis C virus infection. Lancet Infect Dis 2005, 5:558-567.

2. Fischer R, Baumert T, Blum HE: Hepatitis $C$ virus infection and apoptosis. World J Gastroenterol 2007, 13:4865-4872.

3. Mankouri J, Dallas ML, Hughes ME, Griffin SD, Macdonald A, Peers C, Harris M: Suppression of a pro-apoptotic $\mathrm{K}+$ channel as a mechanism for hepatitis C virus persistence. Proc Natl Acad Sci 2009, 106:15903-15908.

4. Shin EC, Shin JS, Park JH, Kim JJ, Kim H, Kim SJ: Expression of Fas-related genes in human hepatocellular carcinomas. Cancer Lett 1998, 134:155-162.

5. Pitot H: The molecular biology of carcinogenesis. Cancer 1993, 72:962-970.

6. Kumar S: Caspase function in programmed cell death. Cell Death Differ 2007, 14:32-43.

7. Machida K, Tsukamoto H, Liu JC, Han YP, Govindarajan S, Lai MM, Akira S, Ou JH: c-Jun mediates hepatitis C virus hepatocarcinogenesis through signal transducer and activator of transcription 3 and nitric oxide-dependent impairment of oxidative DNA repair. Hepatology 2010, 52:480-492.

8. Panasiuk A, Parfieniuk A, Zak J, Filisiak R: Association among Fas expression in leucocytes, serum Fas and Fas-ligand concentrations and hepatic inflammation and fibrosis in chronic hepatitis C. Liver Int 2010, 30:472-478

9. Basu A, Sato K, Meyer K, Ray RB, Friedman SL, Chang YH, Ray R: Stellate cell apoptosis by a soluble mediator from immortalized human hepatocytes. Apoptosis 2006, 11:1391-1400.

10. Brenne C, Grimm S: The permeability transition pore complex in cancer cell death. Oncogene 2006, 25:4744-4756.

11. Calabrese F, Pontisso P, Pettenazzo E, Benvegnu L, Vario A, Chemello L, Alberti A, Valente M: Liver cell apoptosis in chronic hepatitis C correlates with histological but not biochemical activity or serum HCV-RNA levels. Hepatology 2000, 31:1153-1159.

12. Otsuka M, Kato N, Taniguchi H, Yoshida H, Goto T, Shiratori Y, Omata M: Hepatitis $C$ virus core protein inhibits apoptosis via enhanced $\mathrm{BCl}-\mathrm{xL}$ expression. Virology 2002, 296:84-93.

13. Piazzola G, Nuzzaci M, Vitti A, Napoli, Schiavone M, Piazzola P, Antonaci S, Tortorella C: Apoptotic effects of a chimeric plant virus carrying a mimotope of the hepatitis $C$ virus hypervariable region 1: role of caspases and endoplasmatic reticulum-stress. J Clin Immunol 2012 32:866-876.

14. El-Domyati M, Abo-Elenin M, El-Din WH, Abdel-Wahab H, Abdel-Raouf H, El-Amawy T, Barakat M, Hamdy M: Expression of apoptosis regulatory markers in the skin of advanced hepatitis-C virus liver patients. Indian $\mathrm{J}$ Dermatol 2012, 57:187-193.

15. Zayed RA, Rushdy E, Saleh DA: Detection of HCV RNA in the peripheral blood mononuclear cells of serum HCV RNA-negative Egyptian patients under interferon treatment. Am J Med Sci 2010, 340:435-438.

16. Chary A, Winters MA, Eisen R, Knight TH, Asmuth DM, Holodniy M: Quantitation of hepatitis $C$ virus RNA in peripheral blood mononuclear cells in HCV-monoinfection and HIV/HCV-coinfection. J Med Virol 2012, 84:431-437.

17. Wolf BB, Green DR: Suicidal tendencies: apoptotic cell death by caspases family proteinases. J Biol Chem 1999, 274:20049-20052.

18. Panasiuk A, Parfieniuk A, Zak J, Flisiak R: Association among Fas expression in leucocytes, serum Fas and Fas-ligand concentrations and hepatic inflammation and fibrosis in chronic hepatitis C. Liver Int 2009, 30:472-478.

19. Patel T, Gores G: Apoptosis and hepatobiliary disease. Hepatology 1995 21:1725-1741.

20. Hanafy SM, Shehata OH, Farahat NM: Expression of apoptotic markers BCL-2 and Bax in chronic hepatitis C virus patients. Clin Biochem 2010, 43:1112-1117

21. Faubion WA, Gores GJ: Death receptors in liver biology and pathobiology. Hepatology 1999, 29:1-4.

22. Kerr JFR, Wyllie AH, Currie AR: Apoptosis. A basic biological phenomenon with wide-ranging implications in tissue kinetics. Br J Cancer 1972, 26:18.

23. Patel T, Glores GJ: Apoptosis in liver transplantation: a mechanism contributing to immune modulation, preservation injury, neoplasia, and viral disease. Transplant Surg 2000, 4:42-50.

24. Wang Z, Luo P, Cheng L, Zhang S, Shen J: Hapten-antibody recognition studies in competitive immunoassay of a-zearalanol analogs by computational chemistry and Pearson Correlation analysis. J Mol Recognit 2011, 24:815-823.

25. Leroy V: Other non-invasive markers of liver fibrosis. Gastroenterol Clin Biol 2008, 32:52-57.

26. Kamimoto $Y$, Horiuchi $S$, Tanase $S$, Morino $Y$ : Plasma clearance of intravenously injected aspartate aminotransferase isozymes: evidence for preferential uptake by sinusoidal liver cells. Hepatology 1985, 5:367-375

27. Murakami S, Okubo K, Tsuji Y, Sakata T, Kikuchi M, Hirayama R: Changes in liver enzymes after surgery in anti-hepatitic $C$ virus-positive patients. World J Surg 2004, 28:671-674.

28. Ong JP, Barnes DS, Younossi ZM, Gramlich T, Yen-Lieberman B, Goormastic M, Sheffield C, Hoercher K, Starling R, Young J, Smedira N, McCarthy P: Outcome of de novo hepatitis $C$ virus infection in heart transplant recipients. Hepatology 1999, 3:1293-1296.

29. Green RM, Flamm S: AGA technical review on the evaluation of liver chemistry tests. Gastroenterology 2002, 123:1367-1384

30. Chu CW, Hwang SJ, Luo JC, Lai CR, Tsay SH, Li CP, Wu JC, Chang FY, Lee SD: Clinical, virologic, and pathologic significance of elevated serum alpha-fetoprotein levels in patients with chronic hepatitis C. J Clin Gastroenterol 2001, 32:240-244.

31. Mohamed MO, Farid K, Emran TM, Attallah AA: Fibro-a score as a simple and useful non-invasive test for predicting significant liver fibrosis in chronic hepatitis C patients. Arab J Gastroenterol 2001, 12:74-79.

32. Crosse K, Umeadi OG, Anania FA, Laurin J, Papadimitriou J, Drachenberg C, Howell CD: Racial differences in liver inflammation and fibrosis related to chronic hepatitis C. Clin Gastroenterol Hepatol 2004, 2:463-468.

33. Hengartner MO, Bryant JA: Apoptotic cell death: from worms to wombats but what about the weeds? Symp Soc Exp Biol 2000, 52:1-12.

34. Li Z, Diehl AM: Innate immunity in the liver. Curr Opin Gastroenterol 2003, 19:565-571.

35. Bedossa P, Poynard T: An algorithm for the grading of activity in chronic hepatitis C. The METAVIR Cooperative Study Group. Hepatology 1996, 24:289-293

36. Sato Y, Nakata K, Kato Y, Shima M, Ishii N, Koji T, Taketa K, Endo Y, Nagataki S: Early recognition of hepatocellular carcinoma based on altered profiles of alpha-fetoprotein. N Engl J Med 1993, 328:1802-1806.

37. Divella R, Lacalamita R, Tommasi S, Coviello M, Daniele A, Garrisi VM, Abbate I, Simone G, Gadaleta C, Paradiso A, Quaranta M: PAI-1, t-PA and circulating hTERT DNA as related to virus infection in liver carcinogenesis. Anticancer Res 2008, 28:223-228. 
38. Park JJ, Park JY, Kim Do Y, Park YN, Ahn SH, Chon CY, Han KH: Prediction of significant fibrosis in chronic hepatitis C patients with normal ALT. Hepatogastroenterology 2011, 58:1321-1327.

39. Albertoni G, Arnoni CP, Araujo PRB, Andrade SS, Carvalho FO, Girao MJBC, Schor N, Barreto JA: Magnetic bead technology for viral RNA extraction from serum in blood bank screening. Braz J Infect Dis 2011, 15:547-552.

40. Albertoni G, Arnoni CP, Araújo PRB, Carvalho FO, Barreto JA: Signal to cut-off $(\mathrm{S} / \mathrm{CO})$ ratio and detection of HCV genotype 1 by real-time PCR one-step method: is there any direct relationship? Braz J Infect Dis 2010, 14:147-151.

41. Albertoni G, Maquigussa E, Pessoa E, Barreto JA, Borges FT, Schor N: Soluble uric acid increases intracellular calcium through an angiotensin IIdependent mechanism in immortalized human mesangial cells. Exp Biol Med (Maywood) 2010, 235:825-832.

42. Selby JV, Friedman GD, Quesenberry CPJ: Precursors of essential hypertension: pulmonary function, heart rate, uric acid, serum cholesterol, and other serum chemistries. Am J Epidemiol 1990, 131:1017-1027.

43. Livak KJ, Schmittgen TD: Analysis of relative gene expression data using real-time quantitative PCR and the 2(-Delta Delta C(T)). Methods 2001, 25:402-408.

44. Boatright KM, Deis C, Denault JB, Sutherlinj DP, Salvesen GS: Activation of caspase-8 and -10 by FLIP(L). Biochem J 2004, 382:651-657.

45. Johnson CR, Jarvis WD: Caspase-9 regulation: an update. Apoptosis 2004, 9:423-427.

46. Castro G, Ramalho LN, Zucoloto S, Martinelli Ade L, Figueiredo JF: HCV virological response during treatment of chronic hepatitis $C$ is associated with liver histological improvement in patients with HCV/HIV co-infection. Braz J Infect Dis 2008, 12:180-185.

47. Campiotto S, Pinho JR, Carrilho FJ, Da Silva LC, Souto FJ, Spinelli V, Pereira LM, Coelho HS, Silva AO, Fonseca JC, Rosa H, Lacet CM, Bernardini AP: Geographic distribution of hepatitis C virus genotypes in Brazil. Braz J of Medical and Biological Research 2005, 38:41-49.

\section{Submit your next manuscript to BioMed Central and take full advantage of:}

- Convenient online submission

- Thorough peer review

- No space constraints or color figure charges

- Immediate publication on acceptance

- Inclusion in PubMed, CAS, Scopus and Google Scholar

- Research which is freely available for redistribution 